\title{
Zrównoważone zarządzanie sektorem wina w Portugalii
}

W artykule analizuje się sektor wina w Portugalii z punktu widzenia zrównoważonego rozwoju. Portugalia jest jednym z tradycyjnych jego producentów, zaś wino jedną ze strategicznych gałęzi jej gospodarki. Przemysł alkoholowy, do którego należy segment wina, jest kontrowersyjny, gdyż z jednej strony obarczony jest stygmatem "grzechu”, ze względu na negatywne konsekwencje społeczne i zdrowotne, $z$ drugiej zaś wino od dawna związane było z boską symboliką, jako element obrządków religijnych. Ponadto niektóre badania wskazują na pozytywny wpływ na zdrowie ograniczonej konsumpcji czerwonego wina. Ze względu na globalny zasięg rynku wina, w artykule przedstawiony został najpierw szerszy kontekst, który wpływa na rynek wina w Portugalii. Następnie przedstawiona została sytuacja wewnętrzna oraz wysiłki w kierunku zrównoważonego rozwoju tego sektora gospodarki Portugalii. Jako metodologię przyjęto analizę literatury z różnych dziedzin wiedzy związanych z winem.

Słowa kluczowe: wino; rynek wina; zrównoważone zarządzanie; Portugalia 